Совершенствование правового регумирования мер пооцрений и взысканий, применяемых к осужденным к Аишению свободы

Л. Л. САНТАШОВА - старший преподаватель кафедры уголовно-исполнительного права и организации воспитательной работы с осужденными ВИПЭ ФСИН России, кандидат юридических наук;

Е. А. ХУдяковА - курсант 4 курса юридического факультета ВИПЭ ФСИН России 
P е ферат

В статье проанализированы актуальные проблемы правового регулирования и применения мер поощрения и взыскания в отношении осужденных, отбывающих наказание в виде лишения свободы. В работе содержится исторический контентанализ действовавших систем мер поощрений и взысканий в разные периоды исторического развития общества и уголовно-исполнительной системы Российской Федерации.

На основе проведенного эмпирического исследования среди 20 сотрудников - начальников отрядов из 13 регионов России, проходящих в ВИПЭ ФСИН России повышение квалификации по программе «Организация воспитательной работы», авторами статьи подготовлен ряд рекомендаций и предложений по совершенствованию действующего законодательства и практики его применения в этой сфере.

В статье обращено внимание на исключение неэффективных мер поощрения из уголовно-исполнительного законодательства Российской Федерации, таких как награждение подарком и денежная премия. Внесены предложения о расширении перечня мер поощрений для обеспечения дифференциации и индивидуализации наказания в виде лишения свободы.

Авторами внесены предложения по совершенствованию мер взысканий, применяемых к осужденным к лишению свободы: увеличить размер дисциплинарного штрафа с учетом инфляции; в общий срок отбывания наказания не засчитывать нахождение осужденного в штрафном изоляторе (ШИЗО), помещении камерного типа (ПКТ) и едином помещении камерного типа (ЕПКТ); дополнить перечень мер взысканий. Кроме того, в статье рассмотрены проблемы признания осужденного злостным нарушителем установленного порядка отбывания наказания.

Ключевые слова: осужденный; меры поощрения и взыскания; меры дисциплинарного воздействия; стимулирующие нормы; нарушение установленного порядка отбывания наказания; злостный нарушитель установленного порядка отбывания наказания; штрафной изолятор; помещение камерного типа; единое помещение камерного типа.

12.00.08 - Уголовное право и криминология; уголовно-исполнительное право

\title{
Improving the legal regulation of incentive measures and penalties applied to those sentenced to imprisonment
}

\author{
L. A. SANTASHOVA - Senior Lecturer at the Department of Penal Law and the \\ Organization of Educational Work with Convicts of the Vologda Institute of Law \\ and Economics of the Federal Penal Service of Russia, Ph.D. in Law;
}

E. A. KHUDYAKOVA - 4th year student of the Law Faculty of the Vologda Institute of Law and Economics of the Federal Penal Service of Russia

Abstract

The article analyzes the current problems of legal regulation and the application of incentives and penalties for convicts serving sentences of imprisonment. The scientific work contains a historical content analysis of the current systems of measures of incentives and penalties in different periods of the historical development of society and the penal system of the Russian Federation.

Based on the conducted empirical research among 20 employees - detachment commanders from 13 regions of Russia, undergoing advanced training the program "Organization of educational work» in the Vologda Institute of Law and Economics of the Federal Penal Service of Russia, the authors of the article prepared a number of recommendations and suggestions for improving the current legislation and its application in this area.

The article draws attention to the exclusion of ineffective incentives from the penal legislation of the Russian Federation, in particular, the award of a gift and a cash prize. Proposals were made to expand the list of incentive measures to ensure the differentiation and individualization of the sentence of imprisonment.

The authors made proposals to improve the penalties applied to those sentenced to imprisonment: to increase the size of the disciplinary penalty, taking into account inflation, not to include the convicted person in a punishment cell and a single chamber type in the general term of serving a sentence, to add the list of penalties. In addition, the article deals 
with the problems of recognizing a convict as a malicious violator of the established order of punishment.

The results of the study can be used in the educational process in the study of legal disciplines, in the law enforcement practice of employees of the penal system of the Russian Federation, as well as for further research in this area.

Ke y w o r d s: convict; incentives and penalties; disciplinary action; stimulating norms; violation of the established order of punishment; malicious violator of the established order of punishment; penal isolator; chamber type room; single room chamber type.

12.00.08 - Criminal law and criminology; penal law

Одной из задач Концепции развития уголовно-исполнительной системы Российской Федерации до 2020 г. является совершенствование системы мер по повышению мотивации осужденных к законопослушному поведению и взысканий к нарушающим установленный порядок отбывания наказания.

Меры поощрения и взыскания играют важнейшую роль в воспитательном воздействии на осужденных к лишению свободы. В период отбывания наказания правовой статус осужденного может изменяться в зависимости от поведения в лучшую или худшую сторону. Для обеспечения более углубленной дифференциации и индивидуализации наказания в виде лишения свободы необходимо расширить действующий перечень мер поощрений и взысканий. В то же время требуется исключить «мертвые», неработающие меры поощрения, такие как денежная премия и награждение подарком. Изменение организационно-правового статуса исправительных учреждений с «бюджетных» на «казенные» привело к невозможности реализации ряда мер. Нерешенным остается вопрос, из каких средств следует выплачивать денежные премии и награждать подарком, если федеральный бюджет на это средств не предусматривает.

Некоторые меры взыскания также нуждаются в корректировке с учетом потребностей правоприменительной практики. Законодателем были проиндексированы денежные средства, которые осужденным разрешено ежемесячно расходовать на приобретение продуктов питания и предметов первой необходимости в зависимости от вида режима и условий отбывания наказания, в соответствии с повышением прожиточного минимума, а дисциплинарный штраф незаслуженно, на наш взгляд, проиндексирован не был. Требует усовершенствования и порядок их применения.

Проблемам совершенствования дисциплинарной практики в отношении осужденных посвящены труды таких ученых, как М. Г. Детков, В. С. Епанешников, А. И. Зуб- ков, П. Е. Конегер, С. И.Кузьмин, А. С. Михлин, В. И. Селиверстов, А. Ф. Сизый, Н. А. Стручков, В. А. Уткин и др. Одной из последних фундаментальных работ в этой области является докторская диссертация С. Л. Бабаяна «Поощрительные институты уголовно-исполнительного права» (2014).

В разные периоды исторического развития общества и уголовно-исполнительной системы менялось представление о системе мер поощрений и взысканий, применяемых к осужденным к лишению свободы. Обратимся к одной из периодизаций уголовно-исполнительного законодательства - по ранее действовавшим исправительнотрудовым кодексам РСФСР.

Так, ИТК РСФСР 1924 г. закреплял такие дисциплинарные меры к осужденным к лишению свободы, как выговор, ограничение или лишение права свидания, ограничение или лишение права выписки, ограничение или лишение права передачи, ограничение права распоряжения числящимися на их счету деньгами в размере не свыше $1 / 4$, изоляция в отдельную камеру на срок до 14 суток с ежедневной выдачей горячей пищи и выводом на прогулку через два дня на третий, понижение в разряде, перевод в другие места заключения.

ИТК РСФСР 1933 г. предусматривал следующие виды мер поощрения: публичное одобрение с занесением в личное дело и доведением до сведения всех лишенных свободы; предоставление свиданий сверх установленной нормы; улучшение питания; премирование деньгами или вещами; осужденным, отбывшим не менее $1 / 3$ срока лишения свободы, за ударную работу и образцовую дисциплину предоставлялся отпуск до 15 дней с зачетом в срок лишения свободы.

К мерам взыскания по ИТК РСФСР 1933 г. относились: замечание; замечание с предупреждением о более строгом взыскании; выговор, объявляемый при проверке и заносимый в личное дело; возмещение причиненного ущерба; ограничение или лишение на срок до одного месяца права свиданий, или права получения передач, или права 
распоряжения числящимися на счету деньгами; отмена части или полностью зачета рабочих дней; перевод на режим штрафной колонии сроком до одного месяца; перевод в места лишения свободы с более строгим режимом или в более отдаленные от места постоянного жительства лишенного свободы.

ИТК РСФСР 1970 г. закреплял следующий перечень мер поощрений: объявление благодарности; занесение на Доску передовиков производства; награждение похвальной грамотой; премирование за лучшие показатели в работе; разрешение на получение дополнительно одной посылки или передачи; разрешение на получение дополнительного краткосрочного или длительного свидания, а также телефонного разговора; разрешение дополнительно расходовать деньги в сумме, составляющей 15 \% от установленного законом размера минимальной месячной оплаты труда, а в воспитательных колониях - в сумме, составляющей $20 \%$ от установленного законом размера минимальной месячной оплаты труда, на покупку продуктов питания и предметов первой необходимости ежемесячно; досрочное снятие ранее наложенного взыскания; перевод в исправительной колонии особого режима осужденных, отбывших не менее 1/3 срока наказания, из помещений камерного типа в обычные жилые помещения в той же колонии; увеличение времени прогулки осужденным, содержащимся в тюрьме на общем режиме, до двух часов, на строгом режиме - до одного часа.

В качестве меры взыскания в ИТК РСФСР 1970 г. были предусмотрены: предупреждение или выговор; внеочередное дежурство по уборке помещений и территории исправительного учреждения, за исключением охранных сооружений; разовое лишение осужденных, содержащихся в воспитательных колониях, посещения кино, концерта, участия в спортивных играх; отмена улучшенных условий содержания; водворение осужденных, содержащихся в исправительных колониях, в штрафной изолятор с выводом или без вывода на работу либо учебу на срок до 15 суток, а содержащихся в воспитательных колониях - в дисциплинарный изолятор на срок до 10 суток; водворение осужденных, содержащихся в тюрьмах, в карцер без вывода на работу или учебу на срок до 15 суток; перевод осужденных, содержащихся в исправительных колониях общего и строгого режима, в помещения камерного типа на срок до шести месяцев, в колониях особого режима - в одиночные камеры на срок до одного года, а в тюрьмах - на строгий режим на срок от двух до шести месяцев; перевод осужденных, содержащихся в обычных жилых помещениях колонии особого режима, в помещения камерного типа в той же колонии.

В УИК РФ также предусмотрены применяемые к осужденным к лишению свободы меры поощрений (ст. 113) и взысканий (ст. 115). В статьи, посвященные мерам поощрения, неоднократно вносились изменения. Так, федеральным законом от 08.12.2003 № 161-ФЗ был исключен п. «д», разрешающий дополнительный телефонный разговор [6], а федеральным законом от 13.07.2015 № 260-Ф3 проиндексированы денежные средства, которые осужденным разрешается расходовать на покупку продуктов питания (с 500 до 1500 руб.) [5].

Полагаем, что действующая система мер поощрений нуждается в дальнейшем совершенствовании. За указанный период в обществе произошли существенные социально-экономические изменения, которые коснулись и уголовно-исполнительной системы, в частности был изменен организационно-правовой статус деятельности исправительных учреждений с бюджетного на казенный. В этой связи многие стимулирующие нормы практически невыполнимы, такие как денежная премия, награждение подарком, поскольку у учреждений нет собственных денег, а предпринимательская деятельность запрещается. В качестве новых мер поощрения С. Л. Бабаян предлагает ввести институт сокращения срока отбывания наказания, который предусматривает уменьшение срока отбывания наказания положительно характеризующимся осужденным к лишению свободы на период не более трех дней в месяц и не более 36 дней в течение года [2, с. 15].

С целью пропаганды правопослушного поведения необходимо информировать о примененных мерах поощрения по отношению к другим осужденным с использованием кабельного телевидения, радиотрансляционной сети, стенной печати, на общих собраниях и т. д. [4, с. 117].

По данной теме нами было проведено эмпирическое исследование среди сотрудников из 13 регионов России, проходящих профессиональную переподготовку по программе «Организация воспитательной работы». В выборке участвовали 20 начальников отрядов. 61,1 \% респондентов считает, что следует исключить из перечня мер поощре- 
ния такие меры, как награждение подарком, денежная премия, противоположного мнения придерживаются 38,9 \% опрошенных.

Что касается включения в УИК РФ новых поощрительных норм, то в ходе проведенного опроса 16,7 \% отметили необходимость дополнить существующий перечень такой нормой, как направление представления в суд о сокращении срока отбывания наказания в виде лишения свободы в исправительном учреждении. 27,8 \% опрошенных предлагают вернуть в качестве меры поощрения занесение на Доску почета осужденных, выполняющих и перевыполняющих норму выработки. За предоставление лицам, успешно обучающимся в учебных заведениях, дополнительного краткосрочного отпуска с выездом за пределы исправительного учреждения на срок до 15 суток высказались всего 16,7 \% респондентов. По мнению 38,8 \% участников опроса, предоставление дополнительных видеосвиданий также будет целесообразной и необходимой мерой дисциплинарного воздействия.

В целях совершенствования предлагаем внести в ст. 113 УИК РФ следующие изменения:

1) пункт «б» ч. 1 - «награждение подарком»- исключить;

2) пункт «в» ч. 1 - «денежная премия» исключить;

3) дополнить ч. 1 следующими мерами поощрения:

- пункт «к» - награждение похвальной грамотой;

- пункт «л» - занесение на доску почета осужденных, выполняющих и перевыполняющих норму выработки;

- пункт «М» - направление представления в суд о сокращении срока отбывания наказания в виде лишения свободы в исправительном учреждении;

- пункт «н» - предоставление лицам, успешно обучающимся в учебных заведениях, дополнительного краткосрочного отпуска с выездом за пределы исправительного учреждения на срок до пятнадцати суток.

Порядок применения мер поощрения также нуждается в совершенствовании. В этих целях предлагаем внести в ст. 114 УИК РФ п. 5 следующего содержания: «Мера поощрения, предусмотренная п. "м" ст. 113 настоящего Кодекса, применятся в отношении осужденных, отбывающих наказание в воспитательных колониях, колониях-поселениях и исправительных колониях общего режима».

В соответствии с ведомственной статистикой о состоянии дисциплинарной прак- тики за второе полугодие 2018 г. осужденным было предоставлено 1059 выездов за пределы исправительного учреждения (в ежегодный отпуск, для предварительного решения вопросов трудового и бытового устройства и по исключительно личным обстоятельствам). Из них не прибыл в установленные сроки по неуважительным причинам всего один человек. Из этого следует, что данный институт оказывает серьезное воспитательное воздействие, а также способствует укреплению социально полезных связей осужденных, смягчению их изоляции от общества.

Меры взыскания - это ответная реакция администрации учреждений на неправомерные действия осужденных в период отбывания наказания посредством применения индивидуальных мер воздействия (санкций) карательного содержания в целях исправления осужденных и предупреждения дальнейших правонарушений в местах лишениясвободы [8, с. 192].

В соответствии с отчетом о состоянии дисциплинарной практики во втором полугодии 2018 г. количество осужденных, признанных злостными нарушителями установленного порядка отбывания наказания (УПОН), составило 294346 чел., всего было зарегистрировано 19412 злостных нарушений порядка отбывания наказания.

Целесообразность введения такой меры взыскания, как предоставление права начальнику отряда объявлять выговор (письменно) признают 72,2 \% респондентов. Поэтому норма о применении начальником отряда выговора устно нуждается в доработке. В связи с этим необходимо предусмотреть право начальникам отряда самостоятельно налагать выговор в письменной форме. Следовательно, ч. 3 ст. 119 УИК РФ нужно изложить в следующей редакции: «Начальники отрядов имеют право применять выговор».

Система мер взысканий, предусмотренная УИК РФ, длительное время не подвергалась изменениям со стороны законодателя. Минюст России поясняет, что размер дисциплинарного штрафа не пересматривался с 2004 г. и составляет 200 руб. [9, с. 18]. Авторы инициативы считают, что с учетом инфляции его нужно повысить до 500700 руб., чтобы учитывать соразмерность взыскания дисциплинарному проступку [3]. Поэтому, на наш взгляд, данное положение требует пересмотра. Согласно результатам проведенного анкетирования наше мнение поддерживают 88,9 \% респондентов. 
В целях совершенствования мер взысканий предлагаем внести в ст. 115 УИК Р Ф следующие изменения:

1) пункт «б» 4. 1 изложить в следующей редакции: «дисциплинарный штраф в размере до пятисот рублей»;

2) дополнить ч. 1:

- пунктом «ж» - «лишение права на краткосрочное или длительное свидание в течение одного месяца»;

- пунктом «з» - «лишение права на получение посылок, передач и бандеролей на срок до одного месяца».

Существуют проблемы и с водворением нарушителей в штрафной изолятор (ШИЗО). Согласно статистике за второе полугодие 2018 г. такая мера взыскания, как водворение в ШИЗО применялась 3133384 раза. При водворении осужденного в ШИЗО оформляются следующие документы на осужденного:

1) постановление о водворении в ШИЗО;

2) рапорт сотрудника, выявившего нарушение, и объяснение осужденного (акт - в случае отказа от дачи объяснения);

3) акт обыска, обхода, осмотра или другие материалы, подтверждающие допущенное нарушение УПОН (копия графиков, объяснения очевидцев совершенного проступка и т. п.);

4) заключение проверки совершенного нарушения (если таковая проводилась с целью выяснения обстоятельства совершенного нарушения или установления личности правонарушителя);

5) медицинское заключение или отметка медицинского работника на постановлении (на день водворения), что осужденный по медицинским показаниям может содержаться в ШИЗО;

6) дневник индивидуально-воспитательной работы с осужденными, в котором делается запись начальника отряда о проделанной беседе с осужденными по факту нарушения и другие записи;

7) камерная карточка, в которой сотрудником оперативного отдела указывается номер камеры для содержания осужденного [7, c. 7].

На законодательном уровне не закреплен период, на который осужденный признается злостным нарушителем [1, с. 201]. Кроме того, четко не сформулированы основания перевода осужденных, содержащихся в строгих условиях отбывания наказания, являющихся злостными нарушителями установленного порядка отбывания наказания, в помещения камерного типа (ПКТ) и единые помещения камерного типа (ЕПКТ), что является пробелом законодательства.

Статус злостного нарушителя УПОН сохраняется за осужденным до конца срока лишения свободы. Во многих регионах по решению администрации исправительного учреждения этот статус снимается. На данные факты обращают внимание лишь сотрудники прокуратуры [7, с. 2].

Случаи перевода в ЕПКТ в качестве меры взыскания в отношении осужденных во втором полугодии 2018 г. были зафиксированы 2427 раз.

Для перевода осужденного в ЕПКТ сотрудники администрации исправительного учреждения подготавливают и собирают материалы, которые необходимы для признания осужденного злостным нарушителем УПОН. К таким материалам относятся:

- акт о нарушении УПОН;

- объяснение осужденного (акт об отказе);

- постановление о переводе в ЕПКТ;

- характеристика осужденного;

- справка о поощрениях и взысканиях [7, c. 15].

Перечень документов, необходимых для перевода в ЕПКТ:

1. Постановление о переводе осужденного в ЕПКТ, подписанное начальником исправительного учреждения и объявленное осужденному.

2. Акт о нарушении УПОН и (или) рапорты сотрудников с указанием даты, времени, конкретного места и обстоятельств допущенного нарушения с резолюцией начальника исправительного учреждения.

3. При наличии свидетелей из числа осужденных объяснения от них, подтверждающие факт нарушения УПОН.

4. Письменное объяснение осужденного по факту нарушения УПОН или акт об отказе от его написания.

5. Постановление или копия постановления начальника исправительного учреждения о признании осужденного злостным нарушителем УПОН в соответствии со ст. 116 УИК РФ.

6. Характеристика на осужденного, подписанная начальником отряда и утвержденная начальником исправительного учреждения.

7. Справка о поощрениях и взысканиях в отношении осужденного за весь период срока отбывания наказания.

8. Психологическая характеристика на осужденного, подписанная начальником отряда и утвержденная начальником исправительного учреждения. 
9. Справки-ориентировки.

10. Медицинское заключение о возможности нахождения в ЕПКТ по состоянию здоровья.

11. Выписка из протокола дисциплинарной комиссии.

С учетом вышесказанного считаем необходимым особое внимание обращать на данные показатели при заполнении справки о поощрениях и взысканиях, подготовке характеристики осужденного, заключения психолога, где следует отражать факты, которые сотрудники считают ключевыми при переводе осужденного в ЕПКТ или тюрьму.

В целях совершенствования порядка применения мер взысканий предлагаем внести в ст. 117 УИК РФ следующие изменения:

- пункт 4 дополнить и изложить в следующей редакции: «Период содержания осужденных в штрафном изоляторе, помещении камерного типа и едином помещении камерного типа в общий срок отбывания наказания не засчитывать» (по результатам проведенного опроса, внесение вышеуказанного изменения в УИК РФ одобрили $77,8 \%$ респондентов);
- пункт 4.1 изложить в следующей редакции: «Осужденные, являющиеся злостными нарушителями установленного порядка отбывания наказания и содержащиеся в штрафном изоляторе (ШИЗО), могут быть переведены из ШИЗО в помещения камерного типа (ПКТ) за неоднократные нарушения установленного порядка отбывания наказания в течение года»;

3) пункт 6.1 изложить в следующей редакции: «Осужденные, являющиеся злостными нарушителями установленного порядка отбывания наказания и содержащиеся в ПКТ, могут быть переведены из помещений камерного типа (ПКТ) в единые помещения камерного типа (ЕПКТ) за злостные нарушения УПОН. При переводе осужденного из ПКТ в ЕПКТ обязательно наличие справки от оперативного отдела о том, что осужденный оказывает негативное влияние на основную массу осужденных».

Таким образом, проведенное эмпирическое исследование позволяет утверждать, что действующая система мер поощрений и взысканий нуждается в совершенствовании с учетом социально-экономических и политических изменений, произошедших в обществе.

\section{СПИСОК ЛИТЕРАТУРЫ}

1. Абатуров А. И. Профилактика злостных нарушений установленного порядка отбывания наказания, совершенных осужденными в исправительных колониях : дис. ... канд. юрид. наук. М., 2009. 264 с.

2. Бабаян С. Л. Поощрительные институты уголовно-исполнительного права (теория и практика применения) : автореф. дис... д-ра юрид. наук. М., 2014. 46 с.

3. Индексация с учетом инфляции. URL: https://www.znak.com/2019-03-19/minyust_predlozhil_uvelichit_shtraf_dlya_ osuzhdennyh za narushenie rezhima (дата обращения: 13.04.2019).

4. Методические рекомендации по применению дисциплинарной практики в исправительных учреждениях (ФсИн России) // Сборник методических рекомендаций ФСИН России. М., 2013. С. 117-126

5. О внесении изменений в Уголовно-исполнительный кодекс Российской Федерации в части увеличения ежемесячных денежных сумм, предусмотренных для приобретения осужденными продуктов питания и предметов первой необходимости : федер. закон от 13.07.2015 № 260-Ф3 // Собр. законодательства Рос. Федерации. 2015. № 29 (ч. І). Ст. 4386

6. О приведении Уголовно-процессуального кодекса Российской Федерации и других законодательных актов в соответствие с Федеральным законом «О внесении изменений и дополнений в Уголовный кодекс Российской Федерации» : федер. закон от 08.12.2003 № 161-Ф3 (ред. от 03.07.2016) // Собр. законодательства Рос. Федерации. 2003. № 50. Ст. 4847.

7. Савушкин С. М. Порядок перевода в единые помещения камерного типа или в тюрьму осужденных, являющихся злостными нарушителями установленного порядка отбывания наказания : метод. рекомендации. Новокузнецк, 2018.

8. Федяев А. Е. Меры взыскания, применяемые к осужденным, отбывающим наказание в исправительных учреждениях Российской Федерации : дис. ... канд. юрид. наук. Омск, 2005. 205 с.

9. Чернышенко Е. В. Проблемы реализации дисциплинарной ответственности в отношении осужденных к лишению свободы // Вестн. ин-та: преступление, наказание, исправление. 2017. № 3 (39). С. 16-19.

\section{REFERENCES}

1. Abaturov A. I. Profilaktika zlostnyh narushenij ustanovlennogo poryadka otbyvaniya nakazaniya, sovershennyh osuzhdennymi $v$ ispravitel'nyh koloniyah : dis. ... kand. yurid. nauk [Prevention of malicious violations of the established order of punishment, committed by convicts in correctional colonies : the diss. ... PhD. In Law]. Moscow, 2009. 264 p. (In Russ.).

2. Babayan S. L. Pooshchritel'nye instituty ugolovno-ispolnitel'nogo prava (teoriya i praktika primeneniya) : avtoref. dis... d-ra yurid. nauk [Incentive institutions of penal law (theory and practice of application) : : author's abstract of the diss. ... Dsc. in Law]. Moscow, 2014. 46 p. (In Russ.).

3. Indeksaciya s uchetom inflyacii [Indexation adjusted for inflation]. Available at: https://www.znak.com/2019-03-19/ minyust_predlozhil_uvelichit_shtraf_dlya_osuzhdennyh_za_narushenie_rezhima (accessed 13.04.2019). (In Russ.). 
4. Metodicheskie rekomendacii po primeneniyu disciplinarnoj praktiki v ispravitel'nyh uchrezhdeniyah (FSIN Rossii) [Methodical recommendations on the application of disciplinary practice in correctional institutions (of the Federal Penal Service of Russia)]. Sbornik metodicheskih rekomendacij FSIN Rossii - Collection of guidelines of the Federal Penal Service of Russia. Moscow, 2013. S. 117-126 (In Russ.).

5. O vnesenii izmenenij v Ugolovno-ispolnitel'nyj kodeks Rossijskoj Federacii v chasti uvelicheniya ezhemesyachnyh denezhnyh summ, predusmotrennyh dlya priobreteniya osuzhdennymi produktov pitaniya i predmetov pervoj neobhodimosti : feder. zakon ot 13.07.2015 № 260-FZ [On amending the Penal Code of the Russian Federation in terms of increasing the monthly sums provided for the purchase of food and basic necessities by the convicted person: Federal Law from 13.07.2015 No. 260-FL]. Sobr. zakonodatel'stva Ros. Federacii - Collection of Legislation of the Russian Federation. 2015. Iss. 29 (part I). Art. 4386. (In Russ.).

6. O privedenii Ugolovno-processual'nogo kodeksa Rossijskoj Federacii i drugih zakonodatel'nyh aktov v sootvetstvie s Federal'nym zakonom «O vnesenii izmenenij i dopolnenij v Ugolovnyj kodeks Rossijskoj Federacii» : feder. zakon ot 08.12.2003 № 161-FZ (red. ot 03.07.2016) [On bringing the Criminal Procedure Code of the Russian Federation and other legislative acts into conformity with the Federal Law « About modification and additions in the Criminal code of the Russian Federation» : Federal Law from 08.12.2003 No. 161-FZ (in red. on 03.07.2016)]. Sobr. zakonodatel'stva Ros. Federacii Collection of Legislation of the Russian Federation. 2003. Iss. 50. Art. 4847. (In Russ.).

7. Savushkin S. M. Poryadok perevoda vedinye pomeshcheniya kamernogotipailiv tyur'mu osuzhdennyh, yavlyayushchihsya zlostnymi narushitelyami ustanovlennogo poryadka otbyvaniya nakazaniya : metod. rekomendacii [The procedure for transferring convicted persons to a single cell-type room or jail who are malicious violators of the established order of punishment serving : guidelines]. Novokuznetsk, 2018. (In Russ.).

8. FedyaevA. E. Meryvzyskaniya, primenyaemye kosuzhdennym, otbyvayushchim nakazanievispravitel'nyh uchrezhdeniyah Rossijskoj Federacii : dis. ... kand. yurid. nauk [Recovery measures applied to convicts serving sentences in correctional institutions of the Russian Federation : the diss. ... PhD. In Law]. Omsk, 2005. 205 p. (In Russ.).

9. CHernyshenko E. V. Problemy realizacii disciplinarnoj otvetstvennosti $v$ otnoshenii osuzhdennyh $k$ lisheniyu svobody [Problems of implementation of disciplinary responsibility in relation to those sentenced to imprisonment]. Vestn. in-ta: prestuplenie, nakazanie, ispravlenie - Bulletin of the Institute: Crime, Punishment, Correction. 2017. Iss. 3 (39). P. 16-19. (In Russ.). 